\title{
Penilaian Kebaruan Desain Industri dalam Perkara Gugatan Pembatalan Hak Desain Industri di Indonesia
}

\author{
Ripael Tampubolon, Ranti Fauza Mayana, Tasya Safiranita Ramli
}

Fakultas Hukum Universitas Padjadjaran, Bandung, Indonesia

Email: ripael0498@gmail.com; ranti_fauza@yahoo.com; tasya_safiranita@yahoo.com

\begin{abstract}
ABSTRAK
Dalam kerangka pembangunan nasional di bidang ekonomi sektor perindustrian, kemampuan intelektual yang dimiliki manusia sangat dibutuhkan dalam merancang atau mendesain suatu barang yang akan diproduksi dan dipasarkan sebagai suatu produk. Rancangan yang dimaksud tersebut inilah yang disebut sebagai Desain Industri. Kepastian hukum terhadap rancangan tersebut tentunya harus dijamin, terutama ketika ada sengketa di Pengadilan. Berdasarkan latar belakang tersebut, penelitian ini bertujuan untuk, pertama, menganalisis penilaian kebaruan Desain Industri berdasarkan UU Desain Industri. Kedua, menganalisis kesesuaian penilaian kebaruan Desain Industri berdasarkan UU Desain Industri dengan perkara Gugatan Pembatalan Hak Desain Industri di Indonesia. Metode penelitian yang akan digunakan adalah yuridis normatif dengan merujuk pada bahan-bahan hukum tertulis dengan mengkaji data sekunder yang berupa bahan hukum primer, sekunder dan tersier yang berkaitan dengan Desain Industri. Hasil penelitian ini menyimpulkan bahwa pertama, penilaian kebaruan dalam Desain Industri harus mengacu pada Pasal 2 ayat (2) UU Desain Industri dan kata "tidak sama" dengan pengungkapan sebelumnya sebagaimana dimaksud dalam Pasal 2 ayat (2) harus ditafsirkan sebagai "significantly differ" sebagaimana dimaksud dalam Pasal 25 ayat (1) TRIPs. Kedua, Penulis menemukan adannya multitafsir terhadap penafsiran kata "tidak sama" dalam Pasal 2 ayat (2) UU Desain Industri di perkara Gugatan Pembatalan Hak Desain Industri di Indonesia.
\end{abstract}

Kata Kunci: Desain Industri, Penilain Kebaruan, Perkara Gugatan Pembatalan Hak Desain Industri.

\section{PENDAHULUAN}

Kesejahteraan umum merupakan salah satu tujuan Negara Republik Indonesia sebagaimana tercantum dalam Pembukaan Undang-Undang Dasar 1945 (UUD 1945). Salah satu realisasi dari tujuan tersebut diwujudkan pada pembangunan disektor industri, sehingga Indonesia tidak dapat menghindari era perdagangan bebas dengan negara-negara lain (Mayana, 2004, p. 1). Atas hal tersebut Indonesia bergabung menjadi anggota Organisasi Perdangangan Dunia atau World Trade Organization (WTO) dan untuk menjamin perdangangan bebas yang adil, stabil dan tidak ada diskriminasi Indonesia turut melakukan pendandatanganan terdahadap Perjanjian Multilateral General Agreement on Tariffs and Trade (GATT). Kemudian Indonesia melakukan ratifikasi terhadap Agreement Establishing the World Trade Organiation melalui Undang-Undang Nomor 7 Tahun 1994 tentang Pengesahan Agreement Establishing The World Trade Organization (Persetujuan Pembentukan Organisasi Perdangan Dunia) (Mayana, 2004, p. 2). Salah satu lampiran dalam perjanjian GATT tersebut ialah Agreement On Trade Related Aspect of Intellectual Property Rights (selanjutnya disebut "TRIPs") yang merupakan salah satu dari 15 isu dalam Persetujuan GATT (Putaran Uruguay) yang mengatur masalah kekayaan intelektual (Saidin, 2019, p. 327). Dengan ditandatanganinya Pernjanjian tersebut, 
maka memiliki konsekuensi logis terhadap para anggota termasuk Indonesia untuk melakukan penyesuaian terhadap hukum kekayaan intelektualnya.

Apabila didasarkan pada Pasal 499 Kitab Undang-Undang Hukum Perdata kekayaan intelektual sendiri merupakan hak kebendaan, hak atas sesuatu benda yang bersumber dari hasil kerja otak atau hasil kerja rasio yang menalar. Untuk melahirkan sebuah hak kekayaan intelektual dibutuhkan pengorbanan tenaga, waktu, pikiran dan juga biaya yang besar sehingga karya yang dihasilkan memiliki nilai dengan manfaat ekonomi yang tinggi dan menjadi aset industri (Purwandoko, 2011, p. 2). Dalam kerangka pembangunan nasional di bidang ekonomi sektor perindustrian, kemampuan intelektual yang dimiliki manusia sangat dibutuhkan dalam membuat rancangan desain pada sebuah produk untuk menambah daya tarik konsumen karena desain pada produk dapat meningkatkan nilai ekonomi dalam industri. Rancangan pada produk yang dimaksud tersebut disebut sebagai Desain Industri. Setiap negara yang memiliki UU Desain Industri pasti menentukan definisi "desain industri" berdasarkan pemahaman dan kewenangannya masing-masing. Di Indonesia sendiri definisi Desain Industri tercantum dalam Pasal 1 angka 1 Undang-Undang Nomor 31 Tahun 2000 tentang Desain Industri (selanjutnya disebut "UU Desain Industri") yakni;

"..,suatu kreasi tentang bentuk, konfigurasi, atau komposisi garis atau warna, atau garis dan warna, atau gabungan daripadanya yang berbentuk tiga dimensi atau dua dimensi yang memberikan kesan estetis dan dapat diwujudkan dalam pola tiga dimensi atau dua dimensi serta dapat dipakai untuk menghasilkan suatu produk, barang, komoditas industri, atau kerajinan tangan."

Hak atas Desain Industri tidak muncul seketika sesaat desain itu selesai dikerjakan namun hak tersebut diberikan negara setelah dilakukan permohonan pendaftaran kepada Kementerian Hukum dan Ham melalui Direktorat Jenderal Kekayaan Intelektual, dan telah memenuhi persyaratan yang digariskan oleh perundang-undangan. Sehingga dapat dipahami bahwa Desain Industri menganut sistem pelindungan konstitutif yang mengharuskan adanya pendaftaran (first to file system) sebagaimana dimaksud dalam Pasal 12 UU Desain Industri (Fadjri, 2016, p. 1-13). Permohonan pendaftaran Desain Industri diajukan kepada Direktorat Kekayaan Intelektual cq. Direktorat Hak Cipta dan Desain Industri (selanjutnya disebut "DJKI") sebagai lembaga yang memiliki peran dan kedudukan dalam pendaftaran Desain Industri. Namun, apabila terdapat dua atau lebih permohonan atas Desain Industri yang dianggap sama maka hak atas Desain Industri diberikan kepada pemohon yang pertama kali mengajukan Permohonan. Untuk menentukan diterimanya permohonan pendaftaran sebuah desain, DJKI akan melakukan pemeriksaan administratif dan pemeriksaan substantif. Namun, dalam praktiknya tidak jarang ditemukan tumpang tindih Desain Industri yang diterima permohonan pendaftaranya. Pada praktiknya tumpang tindih tersebut diakibatkan oleh pengertian "kebaruan" yang kadang-kadang menimbulkan perdebatan panjang antara pihak yang berwenang menerbitkan sertifikat Desain Industri dengan pendesain yang mengajukan permohonan dan bahkan di tingkat pengadilan pengertian "kebaruan" tersebut menjadi perdebatan.

Terdaftarnya desain-desain yang tidak seharusnya dilindungi tersebut menimbulkan sengketa, sehingga menimbulkan banyaknya Gugatan Pembatalan Hak Desain Industri ke Pengadilan Niaga (Kusumaningrum, 2016, p. 277-287). Salah satu Perkara Pembatalan Desain Industri yang terkenal ialah perkara Gugatan Pembatalan Desain Industri "Sepeda Motor Garuda" dengan Desain Industri "Sepeda Motor Honda" pada tahun 2005. Pada pokoknya dalam perkara tersebut dalam pertimbangan hakim ditingkat pertama atau Pengadilan Niaga menyatakan bahwa Desain Industri yang menjadi objek sengketa memiliki kebaruan berdasarkan Pasal 2 UU Desain Industri, namun kemudian pada tingkat kasasi di Mahkamah Agung dalam pertimbanganya hakim menegaskan bahwa Desain Industri "Sepeda Motor Garuda" tetap dianggap ssama dengan Desain Industri "Sepeda Motor Honda" sehingga 
dianggap tidak memiliki kebaruan, hal tersebut didasarkan bahwa untuk dapat dikatakan tidak sama harus terdapat perbedaan yang signifikan.

Namun, walaupun Putusan Mahkamah Agung tersebut sudah menjadi yurisprudensi, masih banyak putusan lain yang berbeda. Salah satu contohnya ialah perkara Desain Industri "Eco Bottle" atau yang lebih dikenal Tupperware dengan Desain Industri "Biolife". Dalam Putusan Mahkamah Agung Nomor 874K/Pdt.Sus.HKI/2017 tertanggal 19 September 2017 pada pokoknya dinyatakan bahwa berdasarkan Pasal 2 ayat (2) UU Desain Industri Desain Industri "Biolife" yang menjadi objek gugatan dianggap tidak sama dengan Desain Industri "Eco Bottle" milik penggugat. Hal tersebut disimpulkan berdasarkan pendapat yang dikemukakan oleh Ahli Prof. Rahmi Jened, S.H., M.H. yaitu "sedikit perbedaan desain pada dasarnya telah menunjukkan adannya kebaruan".

Berangkat dari kedua putusan perkara Gugatan Pembatalan Hak Desain Industri di atas dapat dilihat bahwa terdapat ketidakpastian hukum mengenai batasan sebuah Desain Industri dikatakan sebagai Desain Industri yang baru terutama dalam perkara Gugatan Pembatalan Hak Desain Industri. Berkenaan dengan hal tersebut, ketiadaan penjelasan lebih lanjut dari pengertian "tidak sama" pada Pasal 2 ayat (2) UU Desain Industri, dapat menimbulkan kerancuan yang luar biasa dengan potensi kerugian yang besar, yaitu dapat digunakannya kedua pemahaman tersebut dalam penyelesain sengketa Desain Industri guna menguntungkan salah satu pihak yang bersengketa. Lebih lanjut, ketidak pastian hukum dalam UU Desain Industri tersebut, apabila ditinjau dari praktik monopoli dan persaingan usaha tidak sehat sangat rentan menimbulkan persaingan usaha tidak sehat karena untuk pihak-pihak yang tidak bertanggungjawab mudah melakukan modifikasi terhadap Desain Industri yang terdaftar dan kemudian mendaftarkannya. Penelitian ini menjadi sangat penting untuk dilakukan mengigat adanya pengamplikasian norma keliru terkait syarat dapat dilindunginya Desain Industri. Maka artikel ini sangat menarik untuk dibahas dan didalami pada penulisan yang berjudul "Penilaian Kebaruan Desain Industri Dalam Perkara Gugatan Pembatalan Hak Desain Industri Di Indonesia".

Berdasarkan latar belakang yang telah diuraikan di atas, terdapat dua rumusan masalah yang akan dikaji, yaitu; pertama bagaimana penilaian kebaruan Desain Industri berdasarkan UU Desain Industri dan kedua bagaimana implementasi penilaian kebaruan dalam Desain Industri pada perkara Gugatan Pembatalan Hak Desain Industri di Indonesia. Dari rumusan masalah yang akan dikaji, maka yang akan menjadi tujuan dari penelitian ini ialah, pertama, untuk mengetahui bagaimana penilaian kebaruan Desain Industri berdasarkan UU Desain Industri. Kedua, bagaimana implementasi penilaian kebaruan dalam Desain Industri pada perkara Gugatan Pembatalan Hak Desain Industri di Indonesia.

\section{METODE PENELITIAN}

Pada penelitian ini akan menggunakan metode penelitian normatif (normative legal research) dengan mengumpulkan dan menganalisis data sekunder. Sehingga pendekatan yang akan digunakan dalam penelitian ini ialah yuridis normatif (statue approach) yang bersifat deskriptif analitis. Pada pokoknya dalam penelitian ini Penulis akan menelusuri dan menganalisis ketentuan-ketentuan hukum yang berkaitan dengan permasalahan yang diteliti yakni Penilaian Kebaruan dalam Desain Industri. Selanjutnya, Penulis juga akan melakukan analisis permasalahan Penilain Kebaruan tersebut terhadap putusan-putusan Gugatan Pembatalan Hak Desain Industri dan salah satu perkara yang akan penulis analisis ialah Putusan Mahkamah Agung Nomor 874K/Pdt.Sus.HKI/ 2017 tertanggal 19 September 2017.

Kemudian dalam penelitian ini Penulis akan menggunakan data sekunder yang berupa bahan hukum primer yakni Undang-Undang Nomor 31 Tahun 2000 tentang Desain Industri, Undang-Undang Nomor 7 Tahun 1994 tentang Pengesahan Agreement Establishing 
The World Trade Organization (Persetujuan Pembentukan Organisasi Perdangan Dunia), Agreement on Trade Related Aspects of Intellectual Property Rights (TRIPs), dan Peraturan Pemerintah Nomor 1 Tahun 2005 tentang Pelaksanaan Undang-Undang Nomor 31 Tahun 2000 tentang Desain Industri. Lalu bahan hukum sekunder yang digunakan berupa literatur hukum dan sumber bacaan lain sebagai bahan hukum tersier. Selanjutnya, teknik pengumpulan data yang akan Penulis gunakan dalam penelitian ini adalah pengumpulan data dengan cara studi dokumen secara daring dengan teknik analisis data dengan mengkaji dan menganalisis norma hukum dalam suatu peraturan perundang-undangan dan dikaitkan dengan kasus yang berkaitan dengan Penilain Kebaruan dalam Desain Industri untuk menjawab permasalahan dalam penelitian ini.

\section{HASIL PENELITIAN DAN PEMBAHASAN}

\section{Penilaian Kebaruan Desain Industri berdasarkan Undang-Undang Nomor 31 Tahun 2000 tentang Desain Industri}

UU Desain Industri dibentuk sebagai konsekuensi logis masuknya Indonesia menjadi salah satu anggota Word Trade Organization (WTO) atau Organisasi Perdangan Dunia, yang mana didalamnya mencakup penyesuaian terhadap Agreement on Trade Related Aspects of Intellectual Property Rights (TRIPs). TRIPs sendiri telah diratifikasi oleh Indonesia, atas hal tersebut TRIPs yang merupakan salah satu lampiran WTO Agreement mengikat bagi Indonesia. Salah satu standar pelindungan bagi karya intelektual dalam TRIPs ialah syarat untuk dapat dilindunginya sebuah Desain Industri yang dapat ditemukan pada Pasal 25 ayat (1) TRIPs. TRIPs dalam hal ini memberikan pilihan atau alternatif sistem pelindungan Desain Industri yang dapat dipilih oleh negara-negara anggota. Pada Pasal 25 ayat (1) TRIPs dinyatakan "member shall provide for the protection of independently created industrial design that are new or original". Jadi pada hakikatnya Indonesia dapat memilih prinsip pelindungan Desain Industri yakni, antara kebaruan seperti halnya pendekatan paten (patent approach) atau original seperti halnya pendekatan hak cipta (copyrigt approach) (Maulana, 2000, p. 173). Lebih lanjut, dalam ketentuan tersebut ditegaskam bahwa jika suatu desain dapat dianggap baru atau original ialah apabila memiliki perbedaan yang signifikan dengan desain yang telah ada sebelumnya.

Melihat ketentuan Pasal 2 ayat (1) UU Desain Industri yang menyatakan bahwa Hak Desain Industri diberikan untuk Desain Industri yang baru, maka pelindungan Desain Industri yang diamanatkan dalam UU Desain Industri ialah" new" atau kebaruan. Pengaturan penilaian kebaruan dalam Desain Industri, pada pokoknya diatur pada Pasal 2 ayat (2) UU Desain Industri yang menyatakan bahwa suatu Desain Industri dianggap baru apabila pada tanggal penerimaan, desain tersebut tidak sama dengan pengungkapan yang telah ada sebelumnya. Pengungkapan yang dimaksud dalam hal ini ialah pengungkapan melalui media cetak, elektronik serta termasuk juga keikutsertaan dalam pameran. Namun, penafsiran kata "tidak sama" dalam Pasal 2 ayat (2) UU Desain Industri dalam praktiknya menimbulkan permasalahan karena tidak terdapat penjelasan lebih lanjut dalam UU Desain Industri, sehingga menimbulkan multitafsir. Penafsiran pertama berangggapan bahwa, untuk dapat dikatakan "tidak sama" cukup dengan perbedaan sedikit, sehingga apabila terdapat 2 (dua) desain yang diperbandingkan maka perbedaan sedikit cukup untuk menyatakan desain tersebut memiliki kebaruan. Kemudian penafsiran yang kedua ialah bahwa "tidak sama" harus diartikan dengan adaanya perbedaan yang signifikan antara 2 (dua) desain yang diperbandingkan, yang mana hal tersebut didasarkan pada standar minimum yang digariskan oleh Pasal 25 ayat (1) TRIPs. Oleh karena itu perbedaan sedikit tetap dikatakan sama sepanjang tampilan secara keseluruhan atau secara substansial masih terlihat sama (Sinungan, 2011, p. 326). 
Pada prakteknya di Indonesia permasalahan penilaian kebaruan Desain Industri tersebut ditemukan pada saat pemeriksaan Desain Industri pada proses pendaftaran yang dilakukan oleh DJKI dan juga pada proses pembuktian pada perkara Gugatan Pembatalan Hak Desain Industri di Pengadilan Niaga khususnya berkaitan dengan desain-desain yang memiliki kemiripan (similarity)( Kementerian Hukum dan Hak Asasi Manusia Republik Indonesia, 2013, p. 1-238). Permasalahan kata "tidak sama" pada Pasal 2 ayat (2) UU Desain Industri tersebut sangat sering terjadi pada perkara Gugatan Pembatalan Hak Desain Industri di Pengadilan Niaga, antara lain yakni sebagai berikut: perkara Gugatan Pembatalan Hak Desain Industri "Furniture Plastik" pada Putusan Pengadilan Niaga Jakarta Pusat Nomor 07/Desain Industri/2004/PN. Niaga.Jkt.Pst; perkara Gugatan Pembatalan Hak Desain Industri "Sepeda Motor Garuda" pada Putusan Mahkamah Agung Republik Indonesia Nomor 022/K/N/HaKI/2005; perkara Gugatan Pembatalan Hak Desain Industri "Mesin Gergaji STIHL" Putusan Pengadilan Niaga Jakarta Pusat Nomor 02/ Desain Industri/ 2004/ N.Niaga. Jkt.Pst; perkara Gugatan Pembatalan Hak Desain Industri "Mesin Boiler" pada Putusan Mahkamah Agung Republik Indonesia Nomor 163 PK/Pdt .Sus/2010; dan perkara Gugatan Pembatalan Hak Desain Industri “Botol Biolife” pada tahun 2017.

Pada pokoknya dalam menentukan unsur baru atau tidaknya suatu desain merupakan suatu hal yang sulit, bahkan persepsi kebarun bagi masyarakat industri belum tentu sama dengan persepsi kebaruan menurut pendesain (Mayana, 2004, p. 146). Untuk melakukan penilaian "kebaruan" tidak terlepas dari unsur-unsur pokok pada defenisi Desain Industri sebagaimana yang tercantum dalam Pasal 1 angka 1 UU Desain Industri. Berkenaan dengan definisi tersebut, dapat dibagi menjadi beberapa unsur pokok sebagai berikut:

1) suatu kreasi tentang bentuk, konfigurasi, atau komposisi garis atau warna, atau garis dan warna, atau gabungan daripadanya;

2) berbentuk tiga dimensi atau dua dimensi yang memberikan kesan estetis;

3) dapat diwujudkan dalam pola tiga dimensi atau dua dimensi; dan

4) dapat dipakai untuk menghasilkan suatu produk, barang, komoditas industri, atau kerajinan tangan.

Berdasarkan dari defenisi Desain Industri dalam UU Desain Industri tersebut dapat dipahami bahwa pada dasarnya Desain Industri fokus pada penampilan (appearance). Penampilan di sini adalah bagaimana suatu produk itu terlihat (the way a product look) (Bently, 2001, p. 612). Pemaknaan penampilan tersebut ialah sebagai penampilan yang dihasilkan oleh fitur-fitur Desain Industri yang diterapkan pada penampilan barang, dengan kata lain yang hanya dapat dilihat atau dinilai dengan mata (judged solely by the eye) (Morris, 1987, p. 32). Penampilan yang hanya dapat dinilai dengan mata tersebut berkaitan dengan manfaat estetika (aesthetic merit) atau daya tarik terhadap konsumen (appeal to consumer). Pada Desain Industri desain penampilan visual produk (visual appearance of product) ini dihasilkan dari fitur-fitur visual dari produk (visual fatures of the product). Fitur visual (feature visual) yang berhubungan dengan produk tersebut mencakup; bentuk (shape), konfigurasi (configuration), pola (pattern) atau ornamentasi (ornamentation) dari produk. Bentuk dan konfigurasi ialah aspek tiga dimensional dari desain dan pola yang diterapkan pada permukaan suatu produk (Reynolds, 2005, p. 536). Fitur visual lainnya ialah komposisi garis (compsition of lines) dan komposisi warna (composition of colors) yang merupakan fitur berwujud dua dimensi (World Intelectual Property Organization (WIPO), 1970, p. 1-89).

Penilaian kebaruan Desain Industri dilakukan terhadap kreasi-kreasi atau fitur-fitur Desain Industri yang diterapkan pada produk berdasarkan pada aspek kreasi, waktu, tempat, dan estetika. Pada aspek kreasi, kebaruan Desain Industri berkaitan dengan pertimbangan apakah suatu Desain Industri memiliki kreasi yang identik, berbeda hanya dalam detail immateril, mirip atau berbeda dengan pengungkapan Desain Industri yang telah ada sebelumnya. Selanjutnya dari aspek tempat, sejauh mana lingkup teritorial kebaruan yang 
akan dilindungi melalui sistem pelindungan Desain Industri. Namun, yang paling penting ialah dari aspek estetika bahwa penekanan kebaruan Desain Industri hanya diberikan untuk penampilan suatu produk berupa aspek ornamental yang dapat memberikan kesan estetis (Soeparman, 2013, p. 94). Kesan estetis yang dimaksud ialah terkait dengan rasa keindahan (sense of beauty) yang merupakan rasa yang diterima oleh hati nurani sebagai hal yang menyenangkan, menggembirakan, menarik perhatian dan tidak membosankan (Muhammad, 2011, p. 113).

Mengacu pada salah satu prinsip TRIPs yaitu TRIPS sebagai standar minimum dengan artian bahwa TRIPs memuat ketentuan-ketentuan yang wajib diikuti oleh para negara anggota dan negara anggota dapat menerapkan ketentuan-ketentuan yang lebih luas lagi, asalkan sesuai dengan ketentuan-ketentuan standar yang digariskan oleh TRIPs (Usman, 2003, p. 17). Oleh karena itu, dengan ketidakjelasan mengenai kebaruan dalam UU Desain Industri dan berkaca pada ketentuan standar minumum yang di gariskan oleh TRIPs yaitu "significantly differ", maka seharusnya Indonesia mengacu pada "significantly differ" untuk menafsirkan kata "tidak sama" dalam Pasal 2 ayat (2) UU Desain Industri.

Selaras dengan ketentuan TRIPs tersebut, Andrieansjah Soeparman menegaskan bahwa mengenai penilaian kebaruan untuk Desain Industri tidak dapat dikatakan memiliki nilai kebaruan apabila dalam kenyatakan hanya memiliki perbedaan yang minor (kecil). Lebih lanjut, Andrieansjah Soeparman menjelaskan untuk menentukan sebuah Desain Industri memiliki kebaruan dapat melihat parameter yang lebih luas dengan melihat kondisi atau ciri-ciri sebagai berikut; pertama, dari sudut pandang konsumen apakah suatu produk memiliki nilai estetis atau kemampuan memberikan perhatian dan kategorisasi, kedua dari sudut pandang ahli desain apakah suatu produk memiliki unsur geometris, struktural dan fitur estetis yang berbeda, ketiga menurut TRIPs apakah suatu Desain Industri berbeda signifikan dengan desain sebelumnya dan bukan kombinasi dari desain-desain yang telah ada sebelumnya, dan yang keempat, berdasarkan hukum yang hidup di masyarakat dengan pertimbangan adannya folklor, maka suatu Desain Industri bukan termasuk folkor (Soeparman, 2013, p. 400). Hal tersebut juga didukung oleh, Ansori Sinungan yang pada pokoknya menyatakan bahwa baru dalam Pasal 2 UU Desain Industri ialah ketika memiliki perbedaan yang singnifikan. Oleh karena itu, sedikit perbedaan diantara dua Desain Industri tetap dapat dinyatakan sama secara substansi sejauh keseluruhan masih terlihat sama(Sinungan, 2011, p. 326).

Penerapan pemahamn tersebut juga dapat dilihat pada salah satu putusan yang terkenal dan juga yang telah menjadi yurisprudensi yaitu kasus Motor Garuda, pada Yurisprudensi Mahkamah Agung RI Nomor 022K/N/HaKI/2005/ tertanggal 24 Oktober 2005 dinyatakan:

"Menimbang, bahwa Mahkamah Agung akan mempertimbangkan dahulu mengenai pengertian

"tidak sama" sebagaimana yang dimaksud dalam Pasal 2 ayat (2) Undang-Undang No. 31

Tahun 2000; bahwa oleh karena tidak ada peraturan perundang- undangan yang menjelaskan mengenai pengertian "tidak sama", maka Mahkamah Agung berpedoman pada Pasal 25 ayat (1) TRIPs (Agreement on Trade Related Aspects of Intelectual Property Rights, Including Trade in Counterfeit Goods)."

Lebih lanjut, dalam praktiknya Yurisprudensi tersebut telah menjadi dasar bagi hakim untuk menentukan sebuah Desain Industri memiliki kebaruan, berikut penulis uraikan beberapa putusan tersebut:

1. Putusan Mahkamah Agung Nomor 022K/N/Haki/2006 yang merupakan perkara antara Ferry Sukamto selaku Pemohon Kasasi (sebelumnya merupakan Penggugat) melawan Ir. Susianto selaku Termohon Kasasi (sebelumnya merupakan Tergugat) dan DJKI selaku Termohon Kasasi (sebelumnya merupakan Turut Tergugat); 
2. Putusan Mahmakah Agung Nomor 033K/N/Haki/2006 yang merupakan perkara antara PT Sun Industri selaku Termohon Kasasi (sebelumnya merupakan Penggugat) melawan Kasum Susanto selaku Pemohon Kasasi I (sebelumnya merupakan Tergugat I) dan PT Antara Kusuma selaku Pemohon Kasasi II (sebelumnya merupakan Tergugat II);

3. Putusan Mahkamah Agung Nomor 026K/N/Haki/2007 yang merupakan perkara antara PT Tirta Intimizu Nusantara selaku Termohon Kasasi (sebelumnya merupakan Penggugat) melawan Abdul Malik Jan selaku Pemohon Kasasi (sebelumnya merupakan Tergugat); dan

4. Putusan Mahkamah Agung Nomor 533K/PDT.SUS/2008 yang merupakan perkara antara Jusman Husein selaku Pemohon Kasasi (sebelumnya merupakan Tergugat) melawan Tody selaku Termohon Kasasi (sebelumnya merupakan Penggugat).

Berangkat dari penjelasan di atas dapat dipahami bahwa syarat kebaruan yang digariskan Desain Industri sebagaimana yang dimaksud dalam Pasal 2 UU Desain Industri ialah wajib mengacu kepada ketentuan standar minimum yang diatur di dalam Pasal 25 ayat (1) TRIPs yaitu, harus terpenuhinya syarat perbedaan yang signifikan. Hal tersebut juga sebagai bentuk kepastian hukum terhadap pelindungan Desain Industri terutama untuk menjamin pelindungan terhadap pendesain dari pihak-pihak yang tidak bertanggungjawab.

Kesesuaian Penilaian Kebaruan Desain Industri berdasarkan Undang-Undang Nomor 31 Tahun 2000 tentang Desain Industri dengan Perkara Gugatan Pembatalan Hak Desain Industri di Indonesia

Berkenaan dengan Gugatan Pembatalan Hak Desain Industri diatur pada Pasal 38 UU Desain Industri yang menyatakan bahwa Gugatan Pembatalan Hak Desain Industri dapat diajukan oleh pihak yang berkepentingan dengan alasan sebagaimana dimaksud dalam Pasal 2 atau Pasal 4 kepada Pengadilan Niaga. Alasan pokok gugatan pembatalan sebagaimana dimaksud dalam ayat (1) ialah apabila Desain Industri yang telah terdaftar dianggap tidak baru atau bertentangan dengan peraturan perundang-undangan yang berlaku, ketertiban umum, agama, atau kesusilaan (Permana, 2020, p. 95-108). Menilik dari salah satu alasan Gugatan Pembatalan Hak Desain Industri maka dapat dipahami bahwa pembuktian kebaruan sebuah Desain Industri dapat terjadi pada saat proses perkara Gugatan Pembatalan Hak Desain Industri, dengan membuktikan apakah suatu Desain Industri memiliki kebaruan sehingga dapat terdaftar di DJKI. R. Subekti berpendapat bahwa pembuktian atau membuktikan merupakan meyakinkan hakim tentang kebenaran dalil atau dalil-dalil yang dikemukakan dalam suatu persengketaan (Subekti, 2008, p. 1). Sehingga dalam proses tersebut pembuktian kebaruan Desain Industri akan dilakukan dengan cara mengumpulkan bukti, memperlihatkan bukti sampai pada penyampaian bukti yang berkaitan dengan kebaruan Desain Industri di sidang pengadilan.

Terdapat empat hal-hal yang fundamental yang berkaitan dengan konsep pembuktian itu sendiri, yaitu (Soeparman, 2013, p. 97):

1) Suatu bukti harus relevan (relevant) dengan sengketa atau perkara yang sedang proses dan bukti tersebut berkaitan dengan fakta-fakta yang menunjuk pada suatu kebenaran suatu peristiwa;

2) Suatu bukti harus dapat diterima atau admissible dan biasanya suatu bukti yang diterima dengan sendirinya relevan;

3) Suatu bukti harus memnuhi syarat atau prinsip exclusionary rules yakni prinsip hukum yang mensyaratkan tidak diakuinya bukti yang diperoleh secara melawan hukum; dan 
4) Dalam konteks pengadilan, setiap bukti yang relevan dan dapat diterima harus dapat dievaluasi oleh hakim. Dalam konteks ini memasuki kekuatan pembuktian atau bewijskracht (weinght of the evidence).

Pada pokoknya dalam Hukum Positif di Indonesia, asas pembagian beban pembuktian tercantum dalam Pasal 163 Herzine Indische Reglement (HIR), Pasal 283 Reglement op de Burgelijke dan juga Pasal 1865 Kitab Undang-Undang Hukum Perdata yang mengatur bahwa yang dibebani kewajiban untuk membuktikan ialah pihak yang mendalilkan bahwa ia mempunyai sesuatu hak atau untuk mengukuhkan haknya sendiri ataupun membantah suatu hak orang lain yang menunjuk pada suatu peristiwa. Hal tersebut didasarkan pada asas actori incumbit probatio yang berarti siapa yang menggugat dialah yang wajib untuk membuktikan (Soeparman, 2013, p. 22-23). Demikian halnya dalam proses pembuktian perkara pembatalan hak Desain Industri yang didaftarkan tidak memiliki kebaruan, beban pembuktiannya dibebankan kepada pihak penggugat.

Menurut Sudikno Mertokusumo terdapat tujuh macam alat-alat bukti yaitu alat bukti tertulis, pembuktian dengan saksi, persangkahan, pengakuan, sumpah, pemeriksaan setempat (descente), dan keterangan ahli (expertise) (Mertokusum, 2010, p. 203). Namun semakin berkembangnnya teknologi saat ini, terumata bidang teknologi komputer telah menimbulkan perkembangan alat bukti juga sehingga terdapat alat bukti lain yang dikenal dengan alat bukti elektronik (Fakhriah, 2009, p. 14). Berkenaan dengan hal tersebut dalam penilaian kebaruan Desain Industri bukti data elektronik berupa bukti publikasi dan penggunaan secara komersial suatu Desain Industri sebelum pendaftaran dapat dijadikan sebagai alat bukti yang sah.

Untuk menganalisis mengenai penilai kebaruan dalam Gugatan Pembatalan Hak Desain Industri dapat mengacu pada salah satu putusan yakni Putusan Mahmakah Agung Nomor 874 K/Pdt.Sus.HKI/ 2017 tertanggal 19 September 2017, yang merupakan Gugatan Pembatalan Hak Desain Industri antara Dart Industries, Inc. melawan PT Cahaya Mulia Nusantara, PT Cahaya Morialife Niaga, Lukman Wijaya, Chandra Puspita, Fharoh H. Syarifa Dan Shintya Lim. Pada pokoknya objek gugatan pembatalan dalam perkara tersebut ialah Desain Industri produk botol "Biolife" milik PT Mitramulia Makmur yang mendapat pelindungan dari DJKI untuk pelindungan pada konfigurasi. Dalam dalil gugatannya penggugat yakni dalam hal ini Dart Industries, Inc. menyatakan bahwa Desain Industri "Biolife" yang didistribusikan oleh para tergugat tidak baru sehingga tidak dapat dilindungi oleh hak atas Desain Industri. Kemudian para tergugat dalam jawaban pada pokok perkara menyatakan bahwa menolak tudingan tersebut dan membela diri jika Desan Industri "Biolife" yang telah terdaftar dengan Nomor Pendaftaran IDD 0000044731 di DJK tertanggal 1 Agustus 2014 merupakan desain yang memiliki kebaruan sebagaimana dimaksud dalam Pasal 2 UU Desain Industri.

Berkenaan dengan dalil gugatan penggugat pada pokoknya di dalam persidangan di Pengadilan Niaga pada Pengadilan Negeri Surabaya Nomor 11/HKI.Merk/2016/PN.Niaga.Sby ("Judex Factie perkara No. 11/2016"), Dart Industries, Inc. mengajukan beberapa alat bukti surat yang pada pokoknya memuat hal-hal sebagai berikut:

1. Bukti P-1 dan P-2 yang merupakan salinan pendaftaran Desain Industri dan surat permohonan petikan resmi untuk pendaftaran Desain Industri untuk menunjukkan bahwa Desain Industri "Eco Bottle" milik penggugat terdaftar dengan hak prioritas di DJKI untuk pelindungan pada konfigurasi;

2. Bukti P-3 sampai dengan Bukti P-48 yang merupakan fotocopy produk "Eco Bottle" dan juga contoh produk asli botol "Biolife" yang menunjukkan fakta jika Desain Industri "Biolife" yang didistribusikan para tergugat memiliki kesamaan pada konfigurasi dengan Desain Industri "Eco Bottle" milik penggugat; dan 
3. Bukti P-49 sampai dengan Bukti P-59 yang merupakan contoh produk asli botol "Biolife" yang menunjukkan fakta bahwa untuk tampilan secara langsung produk "Biolife" milik tergugat memiliki kesamaan dengan produk "Eco Bottle" milik penggugat.

Sedangkan pihak tergugat selain mengajukan alat bukti surat untuk membantah dalil gugatan penggugat juga mengajukan dua orang saksi yang bernama Saksi Muntiah Irawati dan Saksi Denda Ayu dan juga satu orang ahli bernama Prof. Rahmi Jened, S.H., M.H., dalam putusan Judex Factie perkara No. 11/2016 yang pada pokoknya memuat hal-hal sebagai berikut:

1. Bukti T.I.II.III.IV.V - 5 dan Bukti T.I.II.III.IV.V - 8 yang merupakan salinan pendaftaran Desain Industri dan surat permohonan petikan resmi untuk pendaftaran Desain Industri untuk menunjukkan bahwa Desain Industri "Biolife" yang didistribusikan tergugat terdaftar dengan hak prioritas di DJKI untuk pelindungan pada konfigurasi; dan

2. Bukti T.I.II.III.IV.V - 1 sampai dengan Bukti T.I.II.III.IV.V - 4 dan Bukti T.I.II.III.IV.V - 7 yang merupakan gambar produk botol "Biolife" untuk menunjukkan bahwa Desain Industri "Biolife" yang didistribusikan tergugat tidak sama dengan Desain Industri "Eco Bottle" milik penggugat.

Selanjutnya Saksi Muntiah Irawati pada pokoknya menerangkan bahwa saksi mengetahui produk tapperware dan juga mengetahui produk Moorlife. Lebih lanjut, saksi juga pernah ditawari produk moorlife tersebut namun saksi tidak tertarik membelinya. Kemudian untuk Saksi Denda Ayu pada pokoknya menerangkan bahwa mengetahui dan pernah melihat produk "Eco Bottle" sedangkan untuk produk "Biolife" tidak mengetahui. Selanjutnya untuk Ahli yang diajukan oleh tergugat yaitu Ahli Prof. Rahmi Jened, S.H., M.H. pada pokoknya menerangkan bahwa, syarat kebaruan dalam Desain Industri adalah "tidak sama" dengan derajat perbedaan yang rendah untuk kebaruan dalam UU Desain Industri. Berbeda dalam TRIPs new adalah significant different yang tentunya tidak mentah-mentah dianggap berlaku di Indonesia. Salah satu contohnya yang disampaikann oleh ahli ialah perbedaan pada tombol produk telepon seluler yang satu berbentuk kotak sedangkan yang lainnya berbentuk bulat, itu sudah cukup untuk menyatakan bahwa terdapat perbedaan. Sehingga kedua produk yang dimaksud dianggap tidak sama.

Bahwa berdasarkan uraian di atas, putusan Judex Factie perkara No. 11/2016 menolak gugatan Dart Industries, Inc. untuk seluruhnya dengan alasan utama jika berdasarkan keterangan yang dikemukakan oleh Ahli Prof. Rahmi Jened, S.H., M.H. yaitu "sedikit perbedaan desain pada dasarnya telah menunjukkan adannya kebaruan". Lebih lanjut, dalam pertimbangan pada putusan tersebut perbedaan yang dimaksud tidak diperbandingkan terhadap konfigurasi masing-masing Desain Industri, dan malah menyertakan warna serta cara pengemasan dari "Biolife". Kemudian dalam Putusan Kasasi yakni Putusan Mahmakah Agung Nomor 874 K/Pdt.Sus.HKI/ 2017 tetap menguatkan Judex Factie perkara No. 11/2016, dengan menolak permohonan kasasi yang diajukan oleh Dart Industries, Inc.. Pada pertimbangan di tingkat kasasi memberikan pertimbangan yang hampir sama dengan pertimbangan pada Judex Factie yakni pada pokoknya dinyatakan bahwa dinyatakan tidak sama pengungkapannya karena terdapat kebaruan baik dari segi tampilannya secara kasat mata, bentuk, komposisi garis, warna atau konfigurasinya. Sehingga akhirnya putusan tersebut menyatakan dan memutuskan hingga berkekuatan hukum tetap bahwa jika desain "Biolife" yang dipasarkan tergugat memiliki kebaruan sebagaimana dimaksud dalam Pasal 2 UU Desain Industri.

Mengacu pada pertimbangan pada Putusan Mahkamah Agung Nomor 874K/Pdt.Sus.HKI/ 2017 tertanggal 19 September 2017 secara nyata menggunakan penafsiran bahwa kebaruan dalam Desain Industri dimaknai sebagai "perbedaan sedikit pada bentuk 
dan konfigurasi untuk dapat menunjukkan adannya kebaruan". Hal ini tentunya berbeda dengan beberapa putusan sebelumnya yang telah menjadi yurisprudensi yang menggunakan penfasiran bahwa tidak sama harus ditafsirkan dengan "significantly differ" sebagaimana dalam Pasal 25 TRIPs. Salah satu contohnya ialah pada pertimbangan Putusan No. 022/K/N/HaKI/ 2006 yang pada pokoknya menyatakan jika desan dianggap baru apabila "do not significantly differ from known designs or combination of know design features". Permasalahan inilah yang menjadi pemikiran dasar dari penulis mengenai potensi kerugian berupa penyalahgunaan wewenang oleh oknum penegak hukum yang dapat menguntungkan pihak tertentu karena adanya 2 (dua) penafsiran yang berbeda.

Untuk menganalisis pertimbangan pada putusan tersebut, selanjutnya akan dibahas mengenai objek perbandingan dalam melihat ketidak samaan kedua Desain Industri tersebut. Bahwa Desain Industri melindungi konfigurasi dari produk "Eco Bottle", sehingga untuk itu guna menentukan adannya perbedaan, perlu diuraikan mengenai konfigurasi yang dimaknai sebagai suatu bagian atau komponen yang diterapakan dalam suatu objek sebagai satu kesatuan dari bentuk. Berkenaan dengan hal tersebut, untuk menentukan adanya persamaan ataupun perbedaan dalam suatu desain pada konfigurasinya. Maka, kedua konfigurasi desain tersebut harus dibandingkan secara keseluruhan (overall). Atas hal tersebut, berkaitan pada pertimbangan pada putusan tersebut yang menyertakan warna serta cara pengemasan dari "Biolife" untuk melihat perbedaan tidak tepat.

Untuk melihat perbandingan konfigurasi yang dimaksud berikut gambar perbandingan konfigurasi antara "Eco Bottle" dengan "Biolife", sebagai berikut:

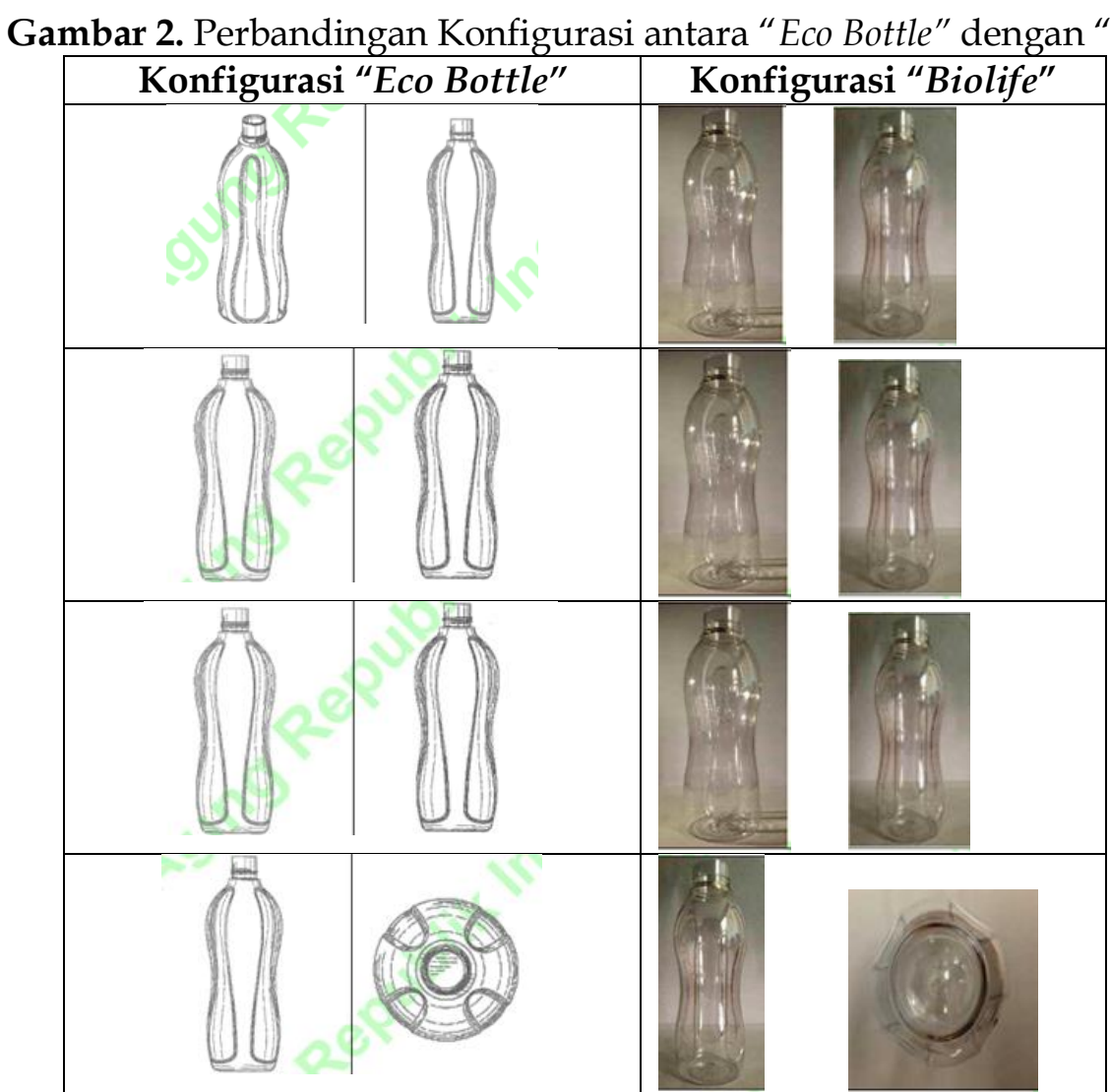

Sumber: Putusan Pengadilan Niaga Surabaya

Nomor 11/HKI/Desain Industri/2016/PN-Niaga SBY

Berangkat dari perbandingan gambar di atas, dalam membandingkan kreasi Desain Industri yang diterapkan pada produk, terdapat skala perbandingan visual yang menunjukkan 
perbandingan Desain Industri yaitu, identik, indentik dengan perbedaan detil immateril, mirip dan tidak sama. Identik yang dimaksud ialah kondisi bahwa perbandingan dua produk yang keduanya memiliki kreasi Desain Industri yang sama persis. Identik dengan perbedaan detil immateril ialah kondisi perbandingan dua produk yang memiliki perbedaan kreasi Desain Industri hanya berupa detil yang sangat kecil perannya sehingga dapat diabaikan. Mirip ialah kondisi perbandingan dua produk yang memiliki kreasi Desain Industri yang secara keseluruhan memiliki kesan tampak yang sama, meskipun ada perbedaan dalam kreasinya. Sedangkan tidak sama adalah kondisi perbandingan dua produk yang memiliki perbedaan baik dari kreasi maupun kesan tampak keseluruhannya sehingga menimbulkan kesan estetis yang berbeda (Soeparman, 2013, p. 400).

Mengacu pada gambar tersebut dan dianalisis dari skala penilai kebaruan di atas dapat dilihat bahwa perbandingan konfigurasi di atas menunjukkan bahwa konfigurasi produk botol "Biolife" yang dipasarkan oleh para tergugat menggunakan konfigurasi empat lekukan mencekung ke dalam di bagian tengah botol (yang tercetak di dalam bentuk botol secara visual menyerupai lekukan angka 8 (delapan) yang memiliki persamaan dengan produk "Eco Bottle' milik penggugat yang telah dilindungi pendaftarannay terlebih dahulu. Perbedaan yang dapat dilihat pada kedua Desain Industri tersebut hanya pada warna dan pada bagian sisi badan botol "Biolife" yang memiliki kreasi ornamentasi berupa tulisan ukiran seni tradisional dari daerah kalimantan (borneo). Namun apabila melihat dari segi konfigurasi kedua Desain Industri tersebut baik dari sisi badan, bagian bawah dan atas, dapat dilihat bahwa terdapat kreasi yang secara keseluruhan memiliki kesan yang sama, walaupun terdapat perbedaan dalam kreasinya. Sehingga dapat disimpulkan perbandingan kedua Desain Industri tersebut ialah mirip, maka masih tetap dianggap sama karena tidak menimbulkan kesan estetis yang berbeda.

Pada pokoknya dalam pertimbangan Putusan Mahkamah Agung Nomor 874k/Pdt.Sus.Hki/2017 tertanggal 19 September 2017 dinyatakan dengan kalimat sebagai berikut, "tidak sama pengungkapannya karena terdapat kebaruan baik dari segi tampilannya secara kasat mata, bentuk, komposisi garis, warna atau konfigurasinya". Dari pertimbangan tersebut, dapat disimpulkan bahwa Putusan Mahkamah Agung Nomor 874k/Pdt.Sus.Hki/2017 tertanggal 19 September 2017 mengacu pada ketentuan penafsiran secara harafiah, dengan kata lain jika ada perbedaan sedikit akan dianggap sebagai desain yang baru. Berdasarkan uraian yang telah dijabarkan di atas, setelah menghubungkan pada Putusan Mahkamah Agung Nomor 874k/Pdt.Sus.Hki/2017 tertanggal 19 September 2017 ketidakjelasan penentuan kebaruan dalam Desain Industri harusnya memperhatikan ketentuan dalam Pasal 25 TRIPs dan juga memperhatikan tolak ukur atau kriteria penilaian Desain Industri terutama penggunaan kesan estetis untuk menentukan kebaruan.

\section{KESIMPULAN DAN SARAN}

\section{Kesimpulan}

1. Pada pokoknya esensi dari pelindungan Desain Industri diatur dalam Pasal 25 TRIPs yang mensyaratkan suatu desain untuk dapat dilindungi harus "new" atau "original" dan kemudian menegaskan bahwa dianggap "new" atau "original", jika desain tersebut "significantly differ" dengan desain yang telah ada sebelumnya. Mengacu pada pengaturan TRIPs tersebut pada prinsipnya sebagai anggota WTO dan TRIPs sebagai standar minimal dalam pelindungan Desain Industri, maka Indoensia untuk menyelesaikan ketidakjelasan dalam UU Desain Industri, dalam melakukan penilaian kebaruan harus menafsirkan kata "tidak sama" dalam Pasal 2 ayat (2) UU Desain Industri sebagai "significantly differ" sebagaimana dimaksud dalam Pasal 25 ayat (1) TRIPs. 
2. Bahwa Penulis menemukan adanya multitafsir terhadap kata "tidak sama" dalam Pasal 2 ayat (2) UU Desain Industri di perkara Gugatan Pembatalan Hak Desain Industri di Indonesia. Salah satunya contohnya ialah perkara Gugatan Pembatalan Hak Desain Industri pada Putusan Mahkamah Agung Nomor 874K/Pdt.Sus.HKI/ 2017 tertanggal 19 September 2017 yang belum sesuai dengan tolak ukur penilain kebaruan dalam UU Desain Industri. Dari pertimbangan putusan tersebut, dapat disimpulkan bahwa Putusan Mahkamah Agung Nomor 874K/Pdt.Sus.HKI/2017 tertanggal 19 September 2017 mengacu pada ketentuan penafsiran secara harafiah, dengan kata lain jika ada perbedaan sedikit akan dianggap sebagai desain yang baru.

\section{Saran}

Untuk memperjelas penilain kebaruan dalam UU Desain Industri perlu adanya revisi terhadap UU Desain Industri dengan mempertegas kata "tidak sama" dalam Pasal 2 ayat (2) UU Desain Industri dengan mengacu pada "significantly differ" sebagaimana dimaksud dalam Pasal 25 ayat (1) TRIPs. Hal ini tentunya akan sejalan dengan semangat pelindungan Kekayaan Intelektual khususnya Desain Industri yang memberikan hak ekslusif kepada pendesain atas kreasinya. Apabila kata tidak sama hanya ditafsirkan secara harafiah maka jika ada perbedaan sedikit akan dianggap baru dan hal tersebut juga akan berdampak pada kreasi pendesain yang tidak berharga.

\section{DAFTAR PUSTAKA}

\section{Buku:}

Muhammad, A. (2011). Ilmu Sosial Budaya Dasar, Bandung: PT Citra Aditya Bakti.

Soeparman, A. (2013). Hak Desain Industri Berdasarkan Penilaian Kebaruan Desain Industri, Bandung: PT Alumni.

Sinungan, A. (2011). Perlindungan Desain Industri Tantangan dan Hambatan dalam Praktiknya di Indonesia, Bandung: PT. Alumni.

Laela, F. E. (2009). Bukti Elektronik dalam Sistem Pembuktian Perdata, Bandung: PT. Alumni.

Maulana, B. I. (2000). Pelangi HaKI dan Monopoli, Yogyakarta: Pusat Studi Hukum (PSH) Fak. Hukum UII Yogyakarta.

Maulana, B. I. (2010). A-B-C Desain Industri Teori dan Praktek di Indonesia, Jakarta: PT Citra Aditya Bakti.

Bently. L and Sherman. B. (2001). Intellectual Property Law, New York: Oxford University Press. Morris, A. I. and Quest, B. (1987). Design: the Modern Law and Practice, London: Butterworth.

Saidin. O. (2019). Aspek Hukum Hak Kekayaan Intelektual (intelektual property rights), Depok: PT Raja Grafindo Persada.

Purwandoko, P. H. (2011). Pokok-Pokok Hak-Hak Kekayaan Intelektual, Surakarta: LPPM UNS.

Subekti, R. (2008). Hukum Pembuktian, Cetakan ke-17, Jakarta: Pradnya Paramita.

Usman, R. (2003). Hukum Hak atas Kekayaan Intelektual, Cetakan Pertama, Bandung: PT Alumni.

Mayana, R. F. (2004). Perlindungan Desain Industri di Indonesia dalam Era Perdagangan Bebas, Jakarta: PT. Gramedia.

Reynolds, R. And Stoianoff, N. P. (2005). Intellectual Property: Text and Essential Cases, New South Wales: The Federation Press.

Mertokusumo, S. (2010). Hukum Acara Perdata Indonesia, Yogyakarta : Liberty.

Peraturan Perundang-Undangan:

-------Undang-Undang Nomor 31 Tahun 2000 tentang Desain Industri

--------Undang-Undang Nomor 7 Tahun 1994 tentang Pengesahan Agreement Establishing

The World Trade Organization (Persetujuan Pembentukan Organisasi Perdangan Dunia)

Agreement on Trade Related Aspects of Intellectual Property Rights (TRIPs) 
-Peraturan Pemerintah Nomor 1 Tahun 2005 tentang Pelaksanaan Undang-Undang Nomor 31 Tahun 2000 tentang Desain Industri

Jurnal:

Fadjri, I. B. S. Dan Njatrijani, R. (2016). "Penerapan Asas Kebaruan (Novelty) dalam Perlindungan Huum Pemegang Hak Desain Industri dari Tindakan Similiaritas di Indonesia". Diponegoro Law Journal 5, No. 3: 1-13.

Kementerian Hukum dan Hak Asasi Manusia Republik Indonesia. (2013). "Naskah Akademik Rancangan Undang-Undang Tentang Desain Industri". Jakarta: Pusat Perencanaan Pembangunan Hukum Nasional Badan Pembinaan Hukum Nasional Kementerian Hukum dan Hak Asasi Manusia: 1-238.

Kusumaningrum, D. A. dan Roisah. R. (2016). “Implimentasi Penilaian Kebaruan dan Prinsip Itikad Baik dalam Perlindungn Desain Industri". Jurnal Law Reform 12, No. 2: 2772087.

Permana, M. R., Haryanto. H. dan Kusumadewi, Y. (2020) "Penerapan Pembatalan Hak Desain Industri Berdaasarkan Gugatan Terkait Adanya Itikad Tidak Baik". Jurnal Krisna Law 2, No. 1: 95-108.

World Intelectual Property Organization (WIPO). (1970). "Model Law for Developing Countries on Industrial Designs". WIPO, Geneva, Publication No. 808 E: 1-89.

\section{Putusan:}

Putusan Pengadilan Niaga Jakarta Pusat Nomor 02/ Desain Industri/ 2004/ N.Niaga. Jkt.Pst Putusan Pengadilan Niaga Jakarta Pusat Nomor 07/Desain Industri/2004/PN. Niaga.Jkt.Pst. Putusan Pengadilan Niaga Surabaya Nomor 11/HKI/Desain Industri/2016/PN-Niaga SBY Putusan Mahkamah Agung Republik Indonesia Nomor 025/ K/N/ HaKI/ 2004

Putusan Mahkamah Agung Republik Indonesia Nomor 010/PK/N/HaKI/2005

Putusan Mahkamah Agung Republik Indonesia Nomor 022/K/N/HaKI/2005

Putusan Mahkamah Agung Republik Indonesia Nomor 022K/N/HaKI/2006

Putusan Mahkamah Agung Republik Indonesia Nomor 163 PK/Pdt .Sus/2010

Putusan Mahkamah Agung Republik Indonesia Nomor 874k/Pdt.Sus.Hki/2017 